\title{
Developing the Imagination Skills among Students with Learning Disabilities in English Language
}

\author{
Mohamad Ahmad Saleem Khasawneh ${ }^{1}$ (D) \\ Email: mkhasawneh@kku.edu.sa \\ ${ }^{1}$ Assistant Professor, Special Education Department, King Khalid University, Saudi Arabia \\ Received: September 15, 2021 \\ Received in Revised: October 17, 2021 \\ Accepted: October 24, 2021
}

\begin{abstract}
This study explored the effect of active learning on developing imagination skills among students with learning disabilities in English language in Irbid city, Jordan. The study used the experimental approach and was applied to a sample of 60 female and male students, who were chosen purposefully. The sample was divided into two groups, an experimental, which was taught using the active learning method, and a control group, which was taught according to the traditional method. The results revealed the existence of significant differences between the performance of the experimental group and the control group on the post-imagination test in favor of the experimental group. The findings also showed statistically significant differences between the scores of the two study groups on the post-imagination test due to the gender variable, and the difference was in favor of males. In light of the findings of the study, the researcher recommended preparing training programs on active learning and preparing a guide for teachers, which can be used to teach and learn reading, writing, and imagination skills in the basic stage.
\end{abstract}

Keywords: Imagination Skills, Active Learning, Students with Learning Disabilities

\section{Introduction}

The term active learning has appeared recently in the twentieth century and more interest have been givem to it toward the beginning of the twenty-first century as one of the contemporary educational and psychological trends, which has a significant positive impact on the learning process inside and outside the classroom on the part of students in schools, institutes, and universities. The technological explosion has been a powerful supportive role in active learning. A large number of websites appeared on the Internet, rich with references, periodicals, articles, field and experimental studies, which contributed to increasing the clarification of the concept of active learning, its importance, and areas of application in many academic disciplines, school subjects and various universities (Saada et al., 2016).

The imagination skill is a creative skill that leads to new ideas that provoke active and real participation from the student. It is required of the student in the school is to use creative imagination, which happens by re-connecting the elements derived from different origins and making them devolve into a new structure. The productive imagination is based on the technology of escalating imagination - that is, raising imagination - as imagination is escalated and aggravated until it achieves better insight and contemplation to reach calmness and intellectual focus for the desired goal. The teacher is also required to be imaginative so that his students can make creative imaginations. Thus, imagination is a strategy in creative teaching that leads to discoveries, new methods, and real-life experiences that will remain in the learner's memory (Guimarães, \& Lima, 2021). 
Imagination deals with long-term memory related to meanings. When a student with learning disabilities is asked about what he wore yesterday, for example, or how many windows in his house, he does not need to take notes and then write them down on paper. Imagination helps the student to retrieve the stored information in the long-term memory. This requires the teacher, when explaining the study material, to resort to tangible material means, and help his students to imagine, then store, fix and restore it when needed later, with the need to note that the process of mental visualization is not necessary to restore all material stored in long-term memory (Tay, 2021).

Imagination can be established in students with learning disabilities as part of persuasive education. It is developed in indirect ways, and its growth depends on the efforts of teachers to consolidate understanding and teaches imagination to students with learning disabilities through contexts, such as learning any subject within the context of imagination to excite the student from the teacher who sets models for imagination.

Modern educational trends focus on finding ways and strategies to develop teaching methods, including the use of imagination in education. Utilizing imagination can increase the opportunity to practice intellectual and symbolic processes, and use the language of art and expression to discover oneself, communicate with and understand others, as well as reach a deeper understanding of cognitive materials. It also helps in developing academic skills, addressing environmental influences, and using it to drive discussions and ideas during problem-solving work sessions (Johnson et al., 2021).

The problem of the study

The development of the skill of imagination is of great importance in the performance of the required learning tasks, and this depends on the ability of the teacher to teach these students using various methods and techniques, including active learning. From the experience of the researcher, he noticed a weakness among students with LDs in the skills of imagination. Therefore, the researcher started from this point of view to research the effect of active learning as a means of addressing the phenomenon of weak imagination skills among students with LDs as one of the teaching strategies. In light of this, the problem of the study is determined in studying the impact of active learning in developing the imagination skills among students with LDs in English language.

\section{Significance of the study}

The importance of the study is summarized in the originality of the subject of the study. The researcher did not find, within the limits of his knowledge, a study that dealt with the same variables on the subject of the study related to the effect of active learning on developing imagination skills. Therefore, this study will constitute an addition to the literature on the topic. In addition to the possibility of benefiting from the results of this study in shaping modern trends of ways to integrate active learning strategies into new educational learning topics.

\section{Limitations}

This study has several limitations. The study is limited to the sample of students with learning disabilities in English language in Irbid Governorate for the academic year 2019/2020. The study is also limited to investigating the effect of active learning on imagination skills.

\section{Literature Review}

\section{Active Learning}

Educators and advocates of the educational process of learning provided many definitions of the concept of active learning, and despite the difference in these definitions in the way they 
were formulated, they agreed in essence and their view of the reality of this concept. Active learning is defined as anything that students do in the classroom other than passively listening to what the teacher says during the lecture, which includes instead positive listening that helps them understand what they hear, writing the most important ideas contained in the sayings, opinions, or explanations, commenting on them, and dealing with them. These activities occur in group exercises and activities in a way that students apply what they have learned in various life situations or solve various daily problems (Guimarães, \& Lima, 2021).

Active learning encourages interaction between the teacher and learners. It also encourages activities that provide quick feedback, and practices that provide sufficient time for learning (Badir, 2019).

There are several benefits to active learning. It enhances listening to the other and allows immediate reactions, and to modify thinking. It often makes students evaluate their ideas and those of peers to determine whether they are appropriate for them, whether they disagree with them, or partially agree with them. It also provides opportunities for students to talk about their ideas and think of better formulations. Students get time to think, discuss, and process information (Badawi, 2016).

\section{Imagination}

Student experiences are stored in the form of mental images that can be linked or compared with other mental images and can be used in combination to produce possible sequences of new mental images. These images can be linked with useful theories to form an understanding of how the universe works, without the need for direct passage into experiences, such as inferences or simulations. These images that are formed in their sequence inside the student's mind are similar to cinematic images that represent a sequence of individual images, each image describes a slight change and during it, the image appears to be continuous with the illusion of movement and imagination (Bennett, 2021).

Imagination is a purposeful mental activity carried out by an individual by imagining existing and non-existent events, based on past experiences that this individual has experienced, to improve the present and develop the future (Johnson et al., 2021).

This strategy is based on six pillars, namely: relaxation, concentration, physical and sensory awareness, and the practice of imagination. It could be expressed verbally or otherwise, such as writing and drawing, to bring the student to the stage of contemplation of those internal fantasies. It is also related to investing them in his practical and scientific life, especially the use of this strategy in developing the student's reading and writing skills. The use of imagination among students can increase the opportunity to practice intellectual and symbolic processes, use the language of art and expression for self-discovery, and communicate with and understand others. It is also helpful to reach a deeper understanding of cognitive materials, develop academic skills, and address environmental influences.

\section{Previous Studies}

Al-Golabi (2021) identified the impact of using a strategy based on imagery through the use of Google Classroom on the imaginative thinking skills in the subject of biolog. The study used the experimental design. The study sample included 68 students in the fourth grade from Baghdad, Iraq. The sample was distributed to two groups, one group was taught using the proposed strategy and the other was taught using the traditional methods. The results showed that students who received the training by the proposed strategy have improved their imaginative thinking skills better than other students. 
Abu Sharkh and Howeidi (2018) identified the effect of an instructional program based on vision-motor imagery in improving achievement among students with LDs in Amman. The study used the experimental design and was applied to a sample of 27 students. The results showed improvement in the academic adjustment of the sample of the study because of the educational program.

Beadle-Brown et al (2018) conducted an intervention based on imagination to help students with autism in the UK. The intervention lasted for 10 months and was applied to 22 students with Autism. The intervention proved to be effective, as all the children, their parents, and their teachers expressed their satisfaction. The study encouraged using the interventions based on imagination with other students with learning disabilities.

Essa (2016) explored the impact of imagery-based training on developing academic selfefficacy among students with learning disabilities. The study included 40 students from the fifth grade in Riyadh. The study collected data by using the self-efficacy test. The results of the study revealed the effectiveness of the training on the students' level of academic selfefficacy

\section{Methods}

\section{Population and Sample}

The number of the study sample was (50) male and female students, distributed in two divisions representing the two study groups. The two divisions were assigned by the random method. Table (1) shows the distribution of the study sample by gender and the total number.

Table 1. Distribution of the study sample according to gender and group

\begin{tabular}{|c|c|c|c|}
\hline Gender & Control Group & Experimental group & Total \\
\hline Male & 15 & 15 & 30 \\
\hline Female & 15 & 15 & 30 \\
\hline Total & 30 & 30 & 50 \\
\hline
\end{tabular}

\section{Instrument of the Study}

The researcher prepared imagination tests as an instrument of the study. The test aimed at measuring the performance of students with learning disabilities in English language, based on the lessons provided to them.

The validity of the imagination test was verified by presenting the objectives and test items in their initial form to a group of specialized and experienced judges. The purpose was for reviewing and reformulating the test items, expressing their opinions in the linguistic form of its vocabulary, and expressing their observations in the test items in terms of clarity of its objectives, and the extent of its comprehensiveness. The judges checked the scientific accuracy of the paragraphs of the test, and their representation of the content and objectives to be measured or any other suggestions. After collecting the judges' notes, some test paragraphs were modified, and some of them were reformulated to become more accurate.

The reliability coefficient of the imagination test used in this study was calculated by applying the test on an exploratory sample of (20) male and female students of the fourth grade from outside the study sample. The test-retest method was used, where the test was applied twice with an interval of two weeks. The reliability coefficient using the Pearson correlation coefficient was calculated, which was (0.89). This value is acceptable and justifies the use of the test for the current study. 


\section{Results and Discussion}

The two questions of the study were answered by calculating the mean scores and standard deviations of the performance of the study members on the pre and post-imagination tests according to the teaching method (active learning method, the regular method). Table (2) shows the results.

Table 2. The mean scores and standard deviations of the study sample's performance on the pre-test and post-imagination test according to the variables of teaching method and gender

\begin{tabular}{|c|c|c|c|c|c|c|}
\hline \multirow{2}{*}{$\begin{array}{c}\text { Teaching } \\
\text { method }\end{array}$} & Gender & \multirow{2}{*}{ No. } & $\begin{array}{c}\text { Mean } \\
\text { score }\end{array}$ & $\begin{array}{c}\text { Standard } \\
\text { deviation }\end{array}$ & $\begin{array}{c}\text { Mean } \\
\text { score }\end{array}$ & $\begin{array}{c}\text { Standard } \\
\text { deviation }\end{array}$ \\
\hline \multirow{3}{*}{ Traditional } & Male & 15 & 41.60 & 17.10 & 52.45 & 11.36 \\
\cline { 3 - 7 } & Female & 15 & 40.53 & 18.63 & 43.13 & 16.32 \\
\cline { 2 - 7 } & Total & 30 & 41.14 & 17.49 & 48.46 & 14.19 \\
\hline \multirow{3}{*}{ Active learning } & Male & 15 & 61.71 & 18.02 & 65.76 & 30.36 \\
\cline { 2 - 7 } & Female & 15 & 43.21 & 9.83 & 52.36 & 10.51 \\
\cline { 2 - 7 } & Total & 30 & 54.31 & 17.50 & 60.40 & 24.95 \\
\hline
\end{tabular}

Table (2) shows that the mean score of the performance of the study sample on the postimagination test who studied using the active learning method was (60.40), which is higher than the mean score of the control group, which was (48.46). The mean score of the performance of the male students was (60.40), which is higher than the mean score of the female students, which was (21.43).

To find out whether the differences between the mean scores of both groups were statistically significant, the accompanying two-way analysis of variance (ANCOVA) was conducted for the effect of teaching method and gender. Table (3) shows the results of the analysis.

Table 3. The results of the (ANCOVA) analysis for the performance of the study sample on the post-imagination test according to the variables of teaching method and gender

\begin{tabular}{|c|c|c|c|c|c|}
\hline $\begin{array}{c}\text { Source of } \\
\text { variance }\end{array}$ & $\begin{array}{c}\text { Sum of } \\
\text { square }\end{array}$ & $\begin{array}{c}\text { Freedom } \\
\text { value }\end{array}$ & $\begin{array}{c}\text { Mean } \\
\text { square }\end{array}$ & F-value & Sig. \\
\hline Pre-test & 102.803 & 1 & 102.803 & 0.241 & 0.625 \\
\hline $\begin{array}{c}\text { Teaching } \\
\text { method }\end{array}$ & 2412.226 & 1 & 2412.226 & 4.597 & $0.021 *$ \\
\hline gender & 2279.511 & 1 & 2279.511 & 5.289 & $0.025 *$ \\
\hline Error & 28455.806 & 66 & 430.164 & & \\
\hline Total & 33238.143 & 69 & & & \\
\hline
\end{tabular}

Table (3) shows that the F value for the teaching method was (5.597), which indicates that there are statistically significant differences between the mean scores of the performance of the two study groups (experimental and control) on the post-imagination test. This means that the active learning method had a significant impact on learning English language among the sample of the study.

Table (3) also shows that the F value concerning the gender variable was (5.289) and at a level of significance (0.025), which indicates that there are no statistically significant differences between the mean scores of the performance of the two study groups (experimental and control) on the post- imagination test due to gender variable. The use of the active learning approach is not affected by the gender of the student. this could be explained by that both genders received the same training and treatment. 
The modified mean scores have been extracted to find out to which group the differences are in favor. Table (4) shows the results.

Table 4. The modified mean scores and standard for the performance of the study sample on the post-imagination test according to the teaching method variable

\begin{tabular}{|c|c|c|c|c|}
\hline Method & Gender & No. & $\begin{array}{c}\text { Mean } \\
\text { score }\end{array}$ & $\begin{array}{c}\text { Standard } \\
\text { deviation }\end{array}$ \\
\hline \multirow{2}{*}{$\begin{array}{c}\text { Traditional } \\
\text { Method }\end{array}$} & Male & 15 & 53.15 & 3.14 \\
\cline { 2 - 5 } & Female & 15 & 41.14 & 3.85 \\
\cline { 2 - 5 } & Total & 30 & 47.14 & 2.68 \\
\hline \multirow{3}{*}{ Traditional } & Male & 15 & 65.66 & 3.31 \\
\cline { 2 - 5 } & Female & 15 & 53.65 & 3.63 \\
\cline { 2 - 5 } & Total & 30 & 59.66 & 2.63 \\
\hline
\end{tabular}

Table (4) shows that the adjusted means score of the experimental group, which studied using the active learning method, was (59.66), while the mean score of the control group that studied using the traditional method was (47.14). This indicates that the difference was in favor of the experimental group, which was studied using the active learning method. This also confirms the effect of this method in developing the imagination skill of third-grade students compared to the traditional method. It is also noted from Table (4) that the adjusted mean score for male students was (59.41), while the adjusted mean score for female students was (47.39), and this indicates that the difference was in favor of males.

The reason for the superiority of the experimental group can be explained by the fact that active learning helped students with learning disabilities learn new methods of study. Active learning also helped them anticipate the information that must be presented, and show how to deal with those stories. It also moved the students to active participation in the scientific discussion of the content of the scientific material, through the sequence of its steps. This strategy also helped in developing the students' metacognitive awareness, through the processes of meditation and imagination.

The active learning strategy focuses on higher-order thinking skills, including metacognitive awareness. This indicates that the students performed imaginative activities in which they process their cognitive systems continuously, and tests and adjust their decision to decide that they consider appropriate for acquiring concepts. Therefore, the active strategy may have contributed to the development of imagination skills by focusing on students with learning disabilities to reflectively imagine the situations that are presented to them.

Active learning may contain basic thinking processes or skills that motivate students with learning disabilities to use those skills when processing the educational material. This led to linking pieces of information and concepts with each other, and building networks of information, organizing information, and retaining it in long-term memory. Active learning supports the skill of encoding information in the student, and it is known that the skill of coding is one of the skills of remembering, and the skill of remembering is one of the basic skills, or central to cognitive thinking.

The results also indicated that there were statistically significant differences between the mean scores of the performance of the two study groups (experimental and control) on the postimagination test due to the gender variable and that the difference was in favor of males. This result may seem biased towards males, but this reality is supported by research. The spatial ability in the brain, which means that the male student can imagine in his mind shapes, places, dimensions, and aspects. It also means the ability to rotate images around one or two axes or a point in his mind and look at them from more than one angle. This characteristic is found in 
four areas of the right lobe of the brain and similar areas in the left section of males, while in females there is no specific area for them and this is what makes them late in this feature than males.

\section{Recommendations}

The study recommends the necessity for researchers interested in developing methods of teaching imagination skills to work on organizing training programs for teachers, based on active learning, and to prepare a guide for teachers that can be referenced when using these programs to learn and teach imagination skills in the basic stage. It is also recommended to train educational supervisors and teachers on practical applications for using the active learning method and evaluating it in the classroom, through the adoption of training programs, and the holding of specialized technical seminars and workshops in this field. English language teachers should use the active learning method in the classroom in the various units of the English language subject in the basic stage.

\section{Acknowledgments}

The authors extend their appreciation to the Deanship of Scientific Research at King Khalid University for funding this work through Big Research Groups under grant number (RGP.2 /103/42).

\section{References}

Abu Sharkh, M. A. \& Howeidi, T. A. F. (2018). The Impact of an Educational Program Based On Vision -Motor Imagery in Improving the Academic Adjustment for the Learning Disabled Children In Amman (unpublished master's thesis). Amman Arab University, Amman. Retrieved from http://search.mandumah.com/Record/98868

Al-Golabi, M. M. A. (2021). The effect of guided imagination strategy using Google Classroom on achievement and imaginative thinking skills of biology among scientific fourth graders. Turkish Journal of Computer and Mathematics Education (TURCOMAT), 12(13), 1616-1624.

Badawi, R. M. (2016). Active Learning. Amman: Dar Al-Fikr for Publishing and Distribution.

Badir, K. M. (2012). Active Learning. 1st Edition. Amman, Dar Al Masirah Publishing.

Beadle-Brown, J., Wilkinson, D., Richardson, L., Shaughnessy, N., Trimingham, M., Leigh, J., Whelton, B \& Himmerich, J. (2018). Imagining Autism: Feasibility of a dramabased intervention on the social, communicative and imaginative behaviour of children with autism. Autism, 22(8), 915-927.

Bennett, A. B. (2021). A whole new learning space: exploring classroom variability for teaching mathematics via active learning. International Journal of Mathematical Education in Science and Technology, 1-23.

Essa, Y. A. S. (2016). The Effectiveness of Training on Guided Imagery on the Development of Academic Self-Efficacy and its Impact on Test Anxiety Among Students with Learning Disabilities. Journal of Special Education: Zagazig University - Faculty of Disability and Rehabilitation Sciences, 16, 357-403. Retrieved from http://search.mandumah.com/Record/753514

Guimarães, L. M., \& Lima, R. D. S. (2021). Active learning application in engineering education: effect on student performance using repeated measures experimental design. European Journal of Engineering Education, 1-21. 
Johnson, A. W., Su, M. P., Blackburn, M. W., \& Finelli, C. J. (2021). Instructor use of a flexible classroom to facilitate active learning in undergraduate engineering courses. European Journal of Engineering Education, 46(4), 618-635.

Tay, H. L. (2021). Using Integrated Course Design for Flipped Classroom to Promote Active Learning of Lean Six Sigma for Supply Chains. International Journal of Management and Applied Research, 8(1), 36-50. 